\title{
Somali Students in the Soviet Union (1960-1978)
}

\section{Lyubov Ivanova}

\section{Introduction}

This article is the analysis of the beginning of Somali-Soviet contacts through the problems of Somali students who came to study in the Soviet Union starting from early 1960s. Their academic success or failure to complete studies and ability to adjust to the way of life in the Soviet Union became the result not only of their personal efforts but also political circumstances and social environment as a whole. Intercultural communication, friendship, misunderstanding or conflicts between Somali students and Soviet citizens became indicators of the psychological preparedness and cultural compatibility/incompatibility for interactions of both sides. Racial prejudices and high mutual expectations also had a great impact on establishing and developing contacts between people of the two countries.

The problems of African students in the Soviet Union have been occasionally discussed at the international conferences, ${ }^{1}$ by Russian and foreign scholars, ${ }^{2}$ there were numerous memoires published by students from African countries who once studied in the Soviet Union ${ }^{3}$. However, students from the Somali Republic have been mentioned rarely and disproportionally (considering the lack of evidence and archival materials) that in turn created their wrong image or misinterpretation of their behaviour. In this study we will concentrate mainly on Somali students and situations they faced in the Soviet Union. Most documents and testimonies cited in the research are published for the first time. 
The chronology of political events helps to trace the transformation of relations between Somalis and the Soviets and explain or foresee possible changes in modern Russia. The article is divided into three main parts. The first part is devoted to the establishing political contacts between the pre-Siyaad Barre regime and the Soviet Union and the arrival of the first Somali students. The second part concerns the problems of Somali students coming from the Socialist Somalia under Barre regime and growth of their confidence in the Soviet support and loyalty. The third part (the period of decline of Somali-Soviet relations due to Ogaden conflict) discusses achievements and failures of educational politics in the Soviet Union as well as peculiarities of Somali attitude to Soviet realities.

This research could help work out strategies for further cooperation between the Somali people and the Russian Federation in the sphere of culture and education for those engaged in this process - officials, public organizations, potential students, their teachers and so on.

\section{Pre-Revolutionary Period (1960-1969)}

\section{A. The First Contacts}

The students from the Somali Republic started to arrive to the Soviet Union in 1961 when the Soviet government launched the programme of Soviet scholarships for students from Asian and African countries. This was the way the Soviets promoted communist ideas across the world, catching the minds of Asian and African students and turning them into "agents of communism." There are no records of Somali presence in the Soviet Union before that time. Though for a number of students from Africa and Asia, the Sixth World Festival of Youth and Students in Moscow in 1957 became the first step in joining the Soviet world, aquiring new friends, and developing ideas of studying there. There is no recorded evidence of the participation of Somalis in the Festival.

Students from the Somali Republic received scholarships offered by the Soviet Afro-Asian Solidarity Committee, Soviet Friendship Societies, Soviet Youth Organizations' Committee, Women's Committee and the Ministry of High, and Secondary and Vocational Education of the USSR.

In the early 1960s, the Soviet Union used the rivalry of the USA, Italy, and Great Britain within the region of the Horn of Africa to 
strengthen its strategic and ideological position in the region. At this time, the knowledge of the Somali realities by the Soviets was quite limited and mostly indirect. In the 19th century in the Horn of Africa, the Russian Empire had closer relations with Christian Ethiopia and French Djibouti. At that time, some Russian doctors and envoys travelled to Ethiopia and visited the Somali coast and regions bordering Ethiopia, leaving some anthropological and ethnographical descriptions of Somalis. In the aftermath of World War II, Soviet diplomats took an active part in the discussions of the fate of ex-Italian colonies on the African continent, including Italian Somalia. In the late 1940s to early 50s, the Soviets had no direct interests in the region, but two decades later it grew into what was called a 'mutually beneficial friendship' between the USSR and Somalia. However, this did not last long, and after just two decades, these relations fell apart. In the late 1970s, after the escalation of territorial conflict in the Horn of Africa and the position of the Soviet government favouring Ethiopia, the Ethiopians remained Soviet friends. Meanwhile, Somalis became enemies of the Soviet Union that resulted in the stagnation of Soviet-Somali relations in all spheres for several decades.

Official diplomatic relations between the Soviet Union and Somali Republic were established on September 11, 1960. On December 30, Gennady Fomin was appointed as the first Soviet Ambassador while A.M. Hassan was appointed as the Somali Ambassador to Moscow. The Jubba hotel in the capital of Mogadishu became the premises for the Soviet Embassy, and the University Institute was chosen as the grounds for Soviet cultural and ideological propaganda. It was equipped with collections of books in Russian and an audio-player with a collection of Russian classical and folk music tapes. The Embassy presented regular expositions in the glass cases of the Jubba hotel displaying photos of how people lived and studied in the Soviet Union. The Embassy also organized shows of Soviet documentary films for Somali politicians and diplomatic officials. Wives of Soviet diplomats were to maintain relations with women's organisations in Somalia through discussion of family life, daily routines, and bringing-up children in the Soviet Union, etc.

In 1961, during the visit of the Somali official delegation to Moscow headed by Prime Minister A. A. Shermarke, a short-term credit of 7 million rubles and a long-term credit of 40 million rubles ${ }^{4}$ were approved for Somalia. This instantly turned the Soviet Union into Somalia's biggest donor. The culmination of Somali military growth, provided by 
the USSR, came during the rule of Siyaad Barre, a few years before the Somali-Ethiopian war over the Ogaden region in 1977-1978.

It must be noted that the Soviet-Somali relations turned to become controversial from the very beginning. The Somali government had been trying to manipulate foreign assistance, searching for the best bargains and negotiating for the best terms. Apart from credits, the Soviet Union exercised technical and military assistance as well as sending Soviet specialists and technicians to teach Somalis. The Somali authorities demanded more and more military equipment in order to protect its territories from neighbours' possible attacks (and to realize the idea of the Greater Somalia-unification of five regions, inhabited by Somalis). The Treaty of Friendship and Cooperation, which was signed between the USSR and the Somali Democratic Republic in 1974, was interpreted differently by both sides. By signing it, the Soviets tried to control Somali territorial ambitions while Somali authorities believed to pursue the dream of Greater Somalia with the Soviet military support. The effectiveness of Soviet technical assistance was not as high as anticipated by Somalis. It often was not adequate and did not meet the real needs of Somali people. In their publications, foreign journalists would mock these inadequacies and failures. ${ }^{5}$

In 1962, the first delegations of Soviet officials, artists, sportsmen, and musicians visited Mogadishu and travelled around the country. Russian language courses were opened and became very popular at the University Institute in Mogadishu. Radio Moscow began broadcasting in Somali language in 1963 (Somali editors translated news from English and Italian into Somali, while Soviet broadcasters acquired theoretical and practical knowledge of the Somali language). ${ }^{6}$ In 1963, Sergey Smirnov, a Soviet historian, started preparations for the first (and the only) Soviet academic expedition to Somalia in search of true reasons for national, anti-colonial and religious movements in the country. The group of Soviet researcher-fellows came to Somalia in 1971 and spent several months interviewing members of political elite, relatives of Sayid Mohamed Abdille Hassan ('mad mullah'), and President Siyaad Barre and his ministers, photographing historical sites, and making public speeches. ${ }^{7}$

In the early 1960s, the mutual interests of Somalia and the Soviet Union were growing and developing in different spheres. Both countries benefited from this cooperation in spite of unequal contribution; both Somalia and the Soviet Union had high expectations and hopes. 


\section{B. The First Students from the Somali Republic}

In 1960, a newly established Patrice Lumumba University of Friendship opened its doors for students from Asian and African countries and remained the most popular among foreign students for decades. Somali students were few at Lumumba University and were scattered among different institutes, universities, and colleges around the Soviet Union. In the early 1960s, a considerable number of Somali students studied in Moscow State University, Kiev State University, Odessa Medical Institute, Odessa Military School, Azerbaijan Petrol and Gaz Institute, Baku Medical College, and other medical and technical colleges of Moscow. ${ }^{8}$ A group of Soviet University lecturers visited colleges in Mogadishu and Hargeysa in 1965. They noted that "the Somali government, is offered 90 Soviet scholarships per year, but prefers to send students directly to institutes and universities, considering that sending students to study for several years in colleges and vocational schools before entering the institute to be a waste of resources and time." ${ }^{\prime 9}$ At the same time, not all Somali students had clear knowledge and a sufficient preparedness to study at a high school level, nor an idea of what specialization to choose. Some Somalis ambitiously wanted to study nuclear physics and others hoped to become cosmonauts. ${ }^{10}$ Meanwhile, the most needed jobs at that time in Somalia were medical doctors, technicians, and military specialists.

Considering these inadequacies, the Soviet lecturers from Voronezh State University while visiting Somalia suggested organizing courses to study the Russian language and other subjects for those who intended to continue their studies in the Soviet Union. ${ }^{11}$ This would have helped the lecturers choose appropriate candidates and help them become better prepared, get good recommendations from Soviet lecturers, and join Soviet universities without any entrance exams. The courses were very popular among Somalis so very soon it was decided to open more Russian language schools.

\section{The First Disillusions and Expressions of Hatred}

Disillusions came quickly. A certain number of students failed to meet the expected educational standards; others had expectations that did not meet Soviet realities, and others did not want to study Marxist ideas. This became a real disappointment for the Soviet authorities. Consequently, activities of these students compounded a deteriora- 
tion of Soviet-Somali relations. But, at the same time, there were other Somali students who successfully obtained Soviet diplomas and secured good jobs back home as governmental officials, doctors, military commanders.

While most Somali students arrived in the Soviet Union directly from the Somali Republic, there were some who had studied at institutes and colleges in Europe due to long-term connections with Italy and Great Britain. The Soviet education system at that time had its advantages and disadvantages when compared against the "western system." It had more restrictions. For instance, students were not allowed to work, they were deprived of opportunities to freely express their ideas and have political gatherings other than authorized communist meetings. While foreign students were given allowances for clothes, travels, etc., they were restricted to travel within the country without special permission. Nevertheless, Somali students in the Soviet Union were quite active in a political sense and were among the first to talk and to write about the things they didn't like. In 1960, during the summer holiday, hundreds of copies of a letter issued by the Committee of Students from Black Africa in the USSR appeared. The letter was written in Russian and, according to Abdul Hamid Hassan, a student from Somalia and an activist of the Committee, was sent to the Administration of Moscow State University only. The Committee intended to send it to the Minister of High Education as well. The letter was copied secretly and distributed around the University. ${ }^{12}$

In the letter, the Committee demanded that the Soviet Government take action to stop racial discrimination against African students. It urged the authorities to change the attitude towards the students from Africa who, they stated, "came to the Soviet Union not as refugees but to study and they deserve to be treated with respect". According to the letter, "Soviet students think that Africans have come from poor countries and are given too much comfort here" ${ }^{13}$

The year of 1960 in the life of students of Moscow State University was also marked by an incident with Abdulhamid Mohammed Hussein, a Somali student. It must be noted that Soviet and Somali officials interpreted this incident differently. Abdulhamid invited a girl to dance with him, but she refused, choosing one of her friends instead. After the dance Hussein went up to her and spit in her face. She then slapped him. Other students intervened and advised the girl to leave, which she did; but one of the Russian men present was so offended by Hussein's behaviour that he demanded an explanation and apology. 
Hussein grabbed the man by the jacket and hit him —and thus began a fight. ${ }^{14}$ The Somali student was beaten by four Russian males and left unconscious. African students' reactions to this incident varied-there were both critics and sympathizers.

About this time, there appeared another leaflet in English and Italian titled The communists say... The Africans reply. 10 home truths about the People's Friendship University in Moscow. This leaflet was very popular in Mogadishu, as it concerned the experience of seven students from Somalia who studied at Moscow State University and were expelled. The group of Somali students addressed the Prime Minister of Somalia with complaints about both poor living conditions of African students in general and Somali students in particular in the USSR and requested to brought back home. They also suggested that this problem should be conveyed to the United Nations as an act of human rights violation. ${ }^{15}$ The authors of the leaflet noted that Soviet scholarships were available only for families of Somali procommunist elite, and that the funds supplied were not sufficient to pay their daily expenses so the students had to sell their personal belongings. Furthermore, they complained about the constant surveillance by the hosts, the ignorance surrounding Islamic traditions, and compulsory attendance for courses in Marxism-Leninism.

Soviet ideological lectures and courses on Marxism-Leninism were among the most hated by African students. M. Yahya, a Somali dissident having completed his six months of training in the USSR, summarized it in the following way: "I came back home not impressed by Soviet experience. It reminded me the words of Kwame Nkruma: If you want your youth to accept socialism, send them to America, but if you want them to like capitalism, send them to the Soviet Union!"16

In response to anti-Soviet propaganda of the expelled Somali students, G. Fomin, the Soviet Ambassador in Somali Republic, suggested sending some letters written by other Somali students who had studied in the Soviet Union and had positive experiences. He wanted them to "share their positive experience of studying and living in USSR to local Somali newspapers Corriere della Somalia and Somali news". ${ }^{17}$

So in December 1961, Hussein Id Hassan, a member of the League of Great Somalia, addressed his compatriots on the meeting in Mogadishu:

Students in the Soviet Union don't waste their time and concentrate on their studies... As for Soviet attitude - it's difficult to describe Soviet dig- 
nity, respect and high morality. In this huge country with many peoples there are no thieves, murderers, insults, no hatred and even no scandals among people. Every person is quiet and concentrated on his work doing his best. As for racial hatred, Soviets are aware of this disgusting phenomenon from the history of colonial countries. Dear brothers and sisters, if you don't believe my words - so surprising they are - I advise you to go to the Soviet Union and see all this with your own eyes! $!^{18}$

In the early 1960s, seven Somali students who refused to complete their studies in the USSR and left for the west wrote a letter to the prime minister of Somali Republic. In it, they urged "... Somali brothers against coming to the USSR and to experience difficulties and humiliation as we did... We left the Soviet Union with disgust, disillusions and disappointment and we want to bring the case against Soviet authorities and Soviet Friendship University." They wrote about harsh living conditions, high cost of living, non-stop spying, and prohibition of any informal contacts with the Soviets. They asserted that:

There is only one mosque in Moscow that is kept as a museum and a showroom for foreign Muslim guests. At the moment there are 23 students from Somalia in Moscow. They want to leave the country but they are kept by force and under threats...our letters are censored and in most cases never delivered... Soviets pay to Somali and other students to be agents of communism.... We think that Somali government shouldn't let Somali students leave for communist countries for studies or at least tell them the truth about humiliation there. We also urge Somali government to bring our case to the UN for further investigation. ${ }^{19}$

Not all Somali students in the Soviet Union shared such a deep alienation. Thus, "The Union of Somali Students in the USSR" was considered to be one of "the most progressive African students' organisation in the Soviet Union (comprising 470 Somali students)." ${ }^{20}$ Initially it was headed by Hussein Salah, a Moscow State University student. The Union was a part of a bigger organization, "The Union of Somali Students in Europe," with its headquarters in Moscow. In the 1960s, one of the leaders of the Union was Abdiqassim Salad Hassan, a Somali student of Moscow State University (Department of Biology) and a future president of the country (2000-2004). The Union regularly appealed to Somali students in the USSR to use the opportunity to get higher education and to fulfill the national duty: bring back home their skills and knowledge. ${ }^{21}$ The Union was an influential organ to settle conflicts between Somali students and Soviet citizens. 
Somali students were scattered about the Soviet Union. The educational establishments of the Ukrainian Republic were popular with those who wanted to get agricultural or military training. Unfortunately, when the students had any problems with local authorities it took much time to get the attention of their representatives who resided mostly in the capital, despite the fact that ambassadors would visit their compatriots in remoted areas. The warmer climate in southern Soviet republics where Somali students studied was more favourable to them. They also felt more positively of the local population, unless there appeared to be any problems that demanded involvement of Somali officials. While waiting for a resolution, the conflict tensions often grew more intensely.

In 1966, in the south of Russia at the Kuban Agricultural Institute, thirty Somali students split into two groups: supporters and opponents of the Soviet regime. A letter was sent to the Somali Embassy in Moscow on the eve of the visit to the Soviet Union of Aden Abdulle Osman, the Somali president. The authors of the letter feared for their life in Kuban and demanded to be transferred to Moscow universities. They "refused to have any contacts with Soviet students and teachers, to take part in all institute's events, attend courses of Communist Party history, philosophy and political economy." The second group of Somali students, loyal to the Soviet regime, led separatist activities informing the institute and police authorities about their opponents' intentions. $^{22}$

Different attitudes of Somali students toward the Soviet reality were influenced by their background, expectations, and preparedness to cope with difficulties they confronted. Some were not ready to embrace socialist ideology; others became devoted supporters of it.

\section{A Foreigner in the USSR: Two Sides of Life}

Unlike their Soviet classmates and the majority of the Soviet people, Somali students could afford buying fashionable things abroad and in certain shops in the USSR. They could also go to restaurants much more often than ordinary Soviet citizens, let alone non-Soviet students. Those Somali dinners often drew the attention of Soviet militiamen who kept in-detail records in official documents and archives. According to the documents, Somalis often got drunk and started intimidating waitresses, abusing other clients, and behaving quite aggressively. When they were detained by the militiamen, they often claimed not to 
remember anything. Usually, after mediation by the officials from the Somali Embassy, they were released, or, if serious enough of a case, left the Soviet Union. When Somali diplomats tried to defend their compatriots, they rarely accused Soviet citizens of racial intolerance but tried to settle incidents peacefully. Nevertheless some criticism of the Soviet realities appeared. One of the documents revealed:

On 9th of December, 1965 at about 9 pm Somali students were dining at one of Moscow restaurants. One of the Soviet clients sitting next to them, threw his dirty napkin into the students. They asked him why he had done it, but the man started insulting them. The students were then taken to the police station but the group leader Omar Haji Hersi was late and was left alone. "Omar decided to go back to the hotel, but was surrounded by Soviet citizens and severely beaten. Some Bulgarian passersby intervened and took Omar to the hospital. As a result of the incident he lost 4 teeth. The Somali embassy was deeply concerned about the case and hoped Prommashexport organization to investigate the case and compensate medical dental treatment to the Somali student. ${ }^{23}$

Quarrels and fights between Somali students and Soviet citizens as well as between Somali and other African students in the restaurants and other public places became the reason why Somali Ambassador Omar M. Ahmed in 1966 suggested "banning Somali students to go to the central restaurants of Moscow."24

The Ambassador of the Somali Republic recommended Soviet authorities reduce the number of Soviet scholarships and select candidates more rigorously, especially for military training. The Ambassador pointed out that "in most criminal cases when Somali students were involved they were accused of drinking alcohol and being guilty without any detailed trial while Soviet people who were obviously guilty in similar cases always escaped any punishment." 25

Official propaganda promoted patronage and friendly relations with foreigners, especially from developing countries, but social environment and the way of life in the Soviet Union was quite different. The Soviets expected students from Asian and African countries that relied on Soviet support and assistance to be more thankful and moderate in expenses. Somali students in turn realized their privileges as foreigners and exhibited it so publicly that the scene eventually caused anger and rising intolerance among the Soviet citizens. It must be said that the expectations from the Soviet and Somali sides were too far apart. The Soviets expected praise and expressions of gratitude but not 
condemnations for their generosity and efforts to help students from post-colonial countries. Somalis, in their turn, preconceived the Soviet Union as a paradise on Earth. Soviet promotion materials intimated the latter impression. Moreover, Somali students could not readily adjust to the demands of study and smooth interactions with Soviet denizens around them. Both groups suffered from vast cultural differences and little knowledge of their respective perspectives, hence, the potential flammability of their encounters. The head of Moscow Transport Institute judged the first Somali students "the worst students, just hooligans." In their turn, African students regarded the Soviets "racists" and identified the Friendship University as "the Apartheid University."

\section{E. Gender Encounters in the Soviet Union}

Close relations between foreigners and local women caused numerous conflicts for both sides. The establishment of the "Iron Curtain" had a great effect on behavioural changes of Soviet women. ${ }^{26}$ For most of them, the Festival of 1957 became the first chance to see and to talk with foreigners. Soviet girls and women were mesmerized and intrigued by different manners, attitudes, and gifts from foreign citizens. Moreover, they were encouraged by Soviet socialist ideology to welcome foreigners and to make friends with them. Female students were appointed by Komsomol to help foreign students with their studies, which is where some of the problems began. Different mentalities and different standards of life turned out to be incomprehensible for Soviet girls and their foreign protégés.

Interpretations of numerous incidents, involving beating, biting, and raping those girls were not clear. For Muslim men, it seemed inappropriate for a girl, in addition not being conservatively dressed, to come to the men's rooms on the campus. On the other side, the girls were sent to fulfill their Komsomol task to help students from developing countries in their studies, and they sometimes were too friendly and tolerant. It is also true that Soviet girls in 1960s were drawn to foreign clothes, music, and access to shops and restaurants available mostly to foreigners. ${ }^{27}$

The archive of the Ministry of Foreign Affairs of the Russian Federation for the period of 1960-1975 houses at least ten documents, open for public access, concerning sexual violence committed by Somali men against Soviet women. This topic has never been discussed publicly. In 
most cases, Somali students were accused of raping female Soviet students who were sent to help them study. Later Somalis never admitted doing it, claiming they didn't remember any details. ${ }^{28}$

According to one file, an 18-year-old Soviet woman was raped by three Somalis in August of 1965; one of the rapist was a Somali embassy official. The woman then committed suicide by throwing herself from the window in a flat belonging to the Embassy. The Ministry of Foreign Affairs of the Somali Republic examined the case and agreed that the mother should receive compensation for her daughter's death. The Government of the Somali Republic paid out the sum of 5060 rubles. ${ }^{29}$ In addition, the parents where invited to come to Mogadishu in August of 1966 as witnesses to the court proceedings against the violators, but the Soviet authorities considered that proposition inappropriate. ${ }^{30}$

Official marriages to foreigners (especially to visually distinctive Black ones) were almost impossible for Soviet women at that time. Though there were single mothers with biracial children, the practice was not approved by the Soviets and caused a great number of problems and inconveniences for women, their children, and their relatives. As for mixed Soviet-Somali descendants and their fate, there is a great deal of research to be conducted.

\section{Students from Post-Revolutionary Somalia}

By the late 1960s, conflicts involving Somali students worsened, thus gaining closer attention of senior Soviet authorities. Osman Hassan, the Somali ambassador, at the meeting in the Committee of the Council on Cultural Relations with Foreign Countries asserted this:

Somali students are expelled when they are in the final year of their studies not for bad progress but for incorrect behaviour. As a result Somalia doesn't get qualified specialists when they have already been well trained. Moreover students leave with broken dreams and in anger. On coming back home they say bad things about Soviet Union that is not good for both countries. ${ }^{31}$

In case of ideological disagreement, the Secretary of the Somali Embassy advised "to send Somali students home immediately and not let them influence other students." ${ }^{32}$ Meanwhile, the increasing number of Somali students in educational establishments of USSR, 
the increasing amount of Soviet aid to Somalia, and growing Somali opposition against the Soviet system of education made Somalis feel more confident and more exacting in their demands from the Soviet authorities.

In 1970, Somalis celebrated the first anniversary of Somali October Revolution of 1969 in one of the best restaurants in Moscow. One of the privileged guests was Hassan Mohamed Siyaad Barre, the son of the Somali president and a student of Kuibyshev Military Academy. The celebration was later described in the police report in the following way:

The incident started when Hassan broke a glass and when asked, refused to leave the restaurant. He had a knife in his hand. An employee of the restaurant tried to take the knife from him and broke Hassan's arm. Hassan's friend called the police to settle the case. ${ }^{33}$

At the police office, the President's son said that he remembered nothing of the incident.

During the 1970s, the tally of Somali students in Soviet educational establishments expanded considerably. Correspondingly, the number of problems caused by Somalis also grew. For instance, a Somali student who studied at Kuban Medical University in Krasnodar (from 1968) was expelled for "bad progress, not respectful behaviour and uncontrolled drinking of alcohol. In 1970 he arrived in Moscow where he stayed homeless, and behaved aggressively threatening people around with a knife." 34 For some offences (which were not mentioned in the document), the Soviet court sentenced him to five years imprisonment and that became the first case of its type. M. Adan, the Somali ambassador, did his best to change the court verdict. ${ }^{35}$ Somali students' communities tried to protest against the decision by appealing to the Ministry of High, Secondary and Vocational Education of the USSR by sending an ultimatum in which they demanded to stop provocations against Somali students. They accused the Soviet Government and the Communist Party of discrimination of Somali students. The Somali Students Association justified all the crimes committed by this student and threatened to free him using their own methods. ${ }^{36}$ After the mediation by the Somali Ambassador who had a six-hour discussion with the rebels, they agreed to apologize and take back the letter.

Still in the 1970s, the Ministry of High, Secondary and Vocational Education of the USSR recommended to the Soviet Ambassador in the 
Somali Democratic Republic to revise the rules of candidates' selection for the Soviet scholarships, considering the age of applicants (not older than 25-26), marriage status, and graduation date from a school or a college to be no more than five years ago. Furthermore, candidates would have to submit proper educational certificates and other legal documents. ${ }^{37}$ The conditions were quite fair and beneficial for both Soviet and Somali sides, but the head of the Ministry of Culture and High Education of Somalia, Mr. I.M. Ebyaan declared that "in case of such restrictions Somalia will send its students to the West and Arab countries but not to the Soviet Union." ${ }^{38}$ Nevertheless, the Soviet diplomat pointed out that in 1975, from 61 Djibouti candidates, only 41 had any certificates of education, most of them had no birth certificates, and three of them presented false documents. The Soviet Embassy in SDR noticed that "a considerable part of Somali applicants thought of their coming to the Soviet Union as an adventurous trip, they didn't care about their studies and behaved badly - all this proved the lack of their motivation and their bad contribution to economic and social development in Somali Democratic Republic."39

By the middle the decade, the number of incidents in which Somali students died under mysterious circumstances became more pronounced. For example, in 1972 in Leningrad (Saint-Petersburg) a Somali student fell from a window; in 1973 a Somali student of the Thorez Institute of Foreign Languages was found in the street dead; and in 1975, in Kharkov, the mutilated body of another Somali student was found.$^{40}$ In all cases, the police claimed that Somalis were drunk and behaved badly.

\section{Graduates from the USSR and Conflict in Ogaden}

Despite the aforementioned and, to be sure, serious difficulties, the first Somali specialists with Soviet degrees returned home in the mid1960s. Consequently, every Soviet journalist on his visit to Somalia sent an article to Soviet newspapers and magazines about Soviet-trained Somalis. Stories of success were then used as a promotion tool to bring in more students from developing countries. On their part, qualified Somali technicians who opened their own shops, Somali doctors, and military officers were ubiquitous. All voiced their appreciation of the Soviet Government for the precious opportunity to obtain high-level education. Moreover, government officials in the Somali Republic who dealt with Soviet journalists and specialists often mentioned with pride 
having earned Soviet diplomas as well as the fact that they spoke Russian. An example was A. Salad Hassan, the Director of the Crash Programmes in the Barre Government in 1972 who became the President of Somalia in the early 1990s, a graduate of the Moscow State University (see the List of well-known Somalis trained in the Soviet Union).

At first, graduates from the Soviet Union were in high demand in Somalia, especially in the military sphere. Soviet equipment, machines, and vehicles required maintenance and technical specialists had much work. Soviet-trained doctors were popular and respected. Those Somalis who wrote letters to the Embassy of the USSR asking for permission to get certain medical treatment in the Soviet Union were advised to visit Soviet doctors working in Somali hospitals.

Towards the end of the 1970s, alongside the deterioration and complications in the Soviet-Somali relations, the attitude toward Soviet trainees and graduates began to change. The Archive of Ministry of Foreign Affairs include a letter of a Somali medical doctor, a Soviet graduate, dated 1977, who complained about unemployment for doctors in Somali hospitals. The difficulty, he asserted, was that all positions that required high skills had been offered to Chinese doctors. After ten years of study in the Soviet Union, this man was requesting permission to resettle and work in the USSR permanently. ${ }^{41}$ This story remained unfinished. On November 13, 1977, there began an urgent evacuation of Soviet citizens from Somalia after President Siyaad Barre denounced the Treaty of Friendship and Cooperation with the USSR, signed in 1974. The attitude toward the Soviets in Somalia changed swiftly, switching to friendly attitudes toward the USA.

It was not a surprise that most Somali military commanders during the fierce Ogaden conflict of 1977-1978 were graduates of Frunze Military Academy, pitting them against their Soviet tutors who were sent to support Ethiopian troops.

Since the early 1960s, Somali students had often felt annoyed by being called Abyssinians by the Soviet people. Indeed, in those early years, the Soviets, having little knowledge about African people, saw no differences between Somalis and Ethiopians. But, by the end of 1970s, when the escalation of territorial conflict in the Horn of Africa heated up, the Soviets reclassified their identification of ethnic groups in the region. From then on, Ethiopians became partners, whereas Somalis, notwithstanding the broad resemblance to each other, became enemies of the Soviet Union, 
In January 1978, the Somali Government took the decision to bring back all 300 Somali students who were studying in the Soviet Union at that time. The Soviets refused to provide them with free transportation as they were accused of breaking the contract conditions by not completing their studies. ${ }^{42}$ This act, among others, at once accelerated the deterioration in political relations and had a crucial impact on the fate of Somali students for decades to come. ${ }^{43}$

\section{Conclusion}

The Somali Republic and the Soviet Union have had a very complicated history of establishing and developing relations: many successes and numerous failures; trust and distrust; and friendship and hostility. Somali students became instrumental in the different stages of the relations, as well as a tool in the communist and capitalist confrontation. Propaganda had a great impact on students' hopes and expectations, and predetermined a number of conflicts and misunderstandings when they dealt with Soviet authorities and ordinary people. On the other hand, not all students were highly motivated to study hard and achieve success. Moreover, a new difficult language, in addition to the high standards of institutes and universities, required much concentration on studies. Furthermore, Soviet realities were different from what they were promised by Soviet propaganda and described by the media in capitalist countries. To be sure, Soviet people in general were friendly and tolerant with regard to students from developing countries. However, there were degrees of suspiciousness and prejudice at the same time. As for Somali students, they often exaggerated their demands for allowances and living conditions, despite the fact that they were better resourced than Soviet students.

Unfortunately, due to political circumstances, the relations between the SDR and the USSR that lasted about 20 years collapsed and never re-established again to its full capacity.

The relationship between the two peoples is yet to recover, notwithstanding the two decades of mutual collaboration. Today, the political orientations and strategic interests of both countries have changed. This situation requires new approaches. There is a serious gap in Somali studies in Russia, and business preferences of both sides are not clear and reliable. Still, there are a number of older Somalis who fluently speak Russian and seem to be ready to participate in making new connections. 
Somali students in modern Russia are difficult to trace-they arrive privately and confidentially. Using internet resources, they choose an educational establishment on their own. Moreover, there is still a Somali Community in Moscow that helps regulate relations with Russian authorities and settle conflicts within Somali communities. Tuition fees in Russia remain comparatively low and that makes it attractive for foreign students. But it is not the Russian state that is interested in this anymore. On the contrary, it is various institutes and universities that, on their own, express keenness in attracting more foreign students in order to secure more funds.

Among those who come to Russia now are various groups of Somalis, not just students. The new arrivals include contract workers, scientific researchers, members of mixed families, asylum seekers, and transit migrants. As for Russians, their knowledge about Somalia and its people is improving. Slowly, some Russians are traveling to Somalia on business and as tourists. However, academic studies of Somalis is very rare. The research about Somalis in modern Russia is extremely limited. This demands different approaches that take into account different resources. This is particularly challenging to historians and social scientists, given the total lack of archival materials or documents. It must be said that archival documents cited in this article, including police reports, mostly mention negative aspects of Somalis in the USSR. Surely, there were other Somalis who studied with great dedication, behaved respectfully and, therefore, remained unnoticed and undocumented.

I hope this article will provoke discussions and urge Somalis to share their memories about their time in the Soviet Union and modern Russia, providing more balanced information and suggesting ways to improve connections between the two peoples.

\section{Some well-known Somalis who studied in the Soviet Union ${ }^{44}$ :}

Abdiqasim Salad Hassan (born 1941) - President of Somalia (2000-2004), minister of internal affairs and minister of Finance in S. Barre Government. Graduated from Biology Department of Moscow State University.

Abdullahi Ahmed Irro - General, specialist in National Defense. Graduated from the Frunze Military academy.

Abdullahi Yusuf Ahmed (1934-2012) - politician, a founder of Democratic Front for Salvation of Somali. Worked as a military attache in Somali Embassy in Moscow (19651968), became the first president of Puntland. Served as a president of Somalia (20042008). Graduated from Frunze Military Academy. 
Ali Matan Hashi (1927-1978) - military leader, a general, a politician, a member of Supreme Revolutionary Council, the first Somali pilot. Studied in Frunze Military Academy and was commander in chief of Somali Air Forces.

Amina Mohamed Jibril (born 1961) - Kenyan-Somali diplomat and politician. Worked for WTO, WOM, UNO. Graduated from Kiev University, Department of International Relations.

Hawa Abdi - a Somali human rights activist, was nominated for a Nobel Prize in 2012. Studied in Moscow (1964-1971).

Jama Ali Jama - Colonel, a President of Puntland. Studied in Moscow.

Mohamed Adam Ahmed (born 1950) - General, Commander in Chief of Somali Military Forces in 2015. Graduated from Frunze Military Academy.

Mohamed Farrah Hassan Aidid (1934-1996) - advisor in Barre Government, an ambassador to India, the chief of Somali Intelligence Service. Graduated from Frunze Military Academy.

Mohammad Ali Samatar (1931-2016) - Highest ranked General/Politician, Senior Vice Chairman of Supreme Revolutionary Council, Minister of Defense, and Prime Minister. Graduated from Frunze Military Academy.

Mustafa Mohamed Moalim (1943-2009) - Somali pilot, founded the first Aviation School in Somali and became its first director. Graduated from Kiev Air Forces Academy, also studied in Moscow.

Salaad Gabeyre Kediye (1933-1972) - revolutionary leader and a general of Somali National Army. Graduated from Frunze Military Academy.

Zahra Abdulla (born 1966) - minister of Foreign Affairs of Somalia (2012-2014), studied medicine in Moscow.

\section{Notes}

GA RF - State Archive of the Russian Federation.

AVP RF - Archive of Foreign Politics (Ministry of Foreign Affairs) of the Russian Federation

*Some Somali names may be misspelt in the original documents or wrongly transcribed from Russian in English (or from Somali)

1. See African Students in the Soviet Union / Russia: Destinies, Experiences, and Influences on the Development of African Studies, Institute of Africa, Russian Academy of Sciences, 2017; Colloque international 'Elites Maghrebines et Subsahariennes formees en URSS Russie et dans les pays D'Europe de L'Est. Maroc', Mohammedia, 25-26 octobre 2013 and others.

2. See the works of M. Matusevich, J. Hessler, S. Mazov, C. Katsakioris

3. A. Amar. An African in Moscow. London, 1963, W. Anti-Taylor. Moscow Diary. L., 1967 and others.

4. In 1960s, one dollar was equivalent to four rubles.

5. Iron Curtain rises over Mogadishu /East Africa Standard 28 May 1962 (Kenya). AVP RF F.581 Op.5 P.3 L.14 in Russian translation

A. Santini. How we ceded Somalia to the Soviets //Europeo. March,3 1971 AVP RF F.581 Op.15 P.17 D.5 in Russian translation 
6. With no Somali textbooks in Russian and long before the introduction of official Somali alphabet

7. Ucheniye zapiski Sovetsko-Somaliiskoy ekspeditsii. Moscow, 1974

8. AVP RF. F. 581. Op. 6 P. 5 D. 12 L. 80

9. GA RF F. 9606 Op.1 D. 2359 L.39 Reports of the lecturers of Voronezh State University, 1965

10. Ibid.

11. GA RF F.9606 Op.1 D. 2359 Reports of the teachers of Voronezh State University, 1965

12. AVP RF. F. 581 Op.4 P.1 D.6 L. 13-15

13. Ibid.

14. S.V. Mazov, Afrikanskie Studenty v Moskve v God Afriki [African Students in Moscow in the Year of Africa], Vostok, vol. 3 (May-June 1999), pp. 89-91.

15. AVP RF. F. 581. Op.5 P.3 D.14 Enclosed leaflet "The communists say... the Africans reply. 10 home truths about the People's Friendship University in Moscow" L. 73

16. Yahya, M.M. (2008) In Siyaad Barre's Prison: A Brief Recollection, Bildhaan: An International Journal of Somali Studies: Vol. 5, N. 10. http://digitalcommons.macalester.edu/ bildhaan $/$ vol5/iss1/10

17. AVP RF. F.581 Op.5 P.3 D.14 L.59 Soviet Embassy in Somali Republic to the African Department of Ministry of Foreign Affairs of URSS, May 22, 1961

18. AVP RF. F.581. Op.6 P.5 D.10 L.8-11 in Russian translation

19. GA RF F.9606 Op.2 D.49 L.3-6 A Letter from 7 Somali students to Prime-Minister A. Ali, November, 1960

20. GA RF F.9606 Op.1 D.177 L.46-47 Information about the African students' Associations in the USSR

21. GA RF F.9606 Op.1 D.177 L.82-83 Resolution of the Congress of Somali Students held in Moscow January, 27-29 1965

22. GA RF F.9606 Op.2 D.264 L.19-24 Kuban Agricultural Institute to the Ministry of High and Vocational Education, Department of Foreign Students.

23. Ibid. L. 36-37

24. AVP RF F.581 Op.10 P.9 D.2 L. 29 Zaikin's Diaries. Conversation with charge d'affairs of the Somali Republic O.M. Ahmed, November 1, 1966

25. AVP RF F.581 Op.10 P.9 D.2 L.14-18 Fomin's Diaries. Conversation with Somali Ambassador O. Xassan, February 1, 1966

26. For details about women's life in 1950-60s see Women in Khruschev Era. Ed. by M.Ilic, S. Reid, L.Attwood. New York, 2004

27. About African students in general in the USSR see M. Matusevich. An exotic subversive: Africa, Africans and the Soviet everyday //Race and Class 2008 49, 58

28. AVP RF F.581 Op.9 P.8 D.9 L.81 A Letter from the Deputy of State Attorney to A. Malik, the Deputy of Minister of Foreign Affairs

29. AVP RF F.581 Op.12 P.11 D.8 L. 22

30. AVP RF F.581 Op.12 P.11 D.3 L.15 Conversation with Ambassador O.A. Xassan, April

24, 19681 dollar equals 4 roubles. 


\section{Lyubov Ivanova}

31. AVP RF F. 581 Op.9 P.8 D.9 Conversation of Ambassador O. Xassan and the Deputy of the Minister of High, Secondary and Vocational Education, December 14, 1965

32. AVP RF F.581 Op.15 P.17 D.8 L.43 Sivenko's Diaries. Conversation with Counsellor M. Salah and attache M. Adan. June, 14, 1971

33. AVP RF F. 581 Op.14 P.14 D.2 L.30 D.I. Zaikin's Diary. November 3, 1970. Conversation with A.M. Adan, October 23, 1970

34. AVP RF F.581 Op.15 P.17 D.7 Reference materials on Somali.

35. AVP RF F.581 Op.14 P.14 D.2 L.34 Conversation between A.Adan and S. Sinitsin, November 11, 1970

36. AVP RF F.581 Op.14 P.14 D.2 L.31-33 Sokhin's Diaries. Conversation with Ambassador A.Adan, November 16, 10

37. AVP RF F.581 Op.14 P.15 D.12 L.15-16 A letter from S. Sokhin to Soviet Ambassador in Somalia A. Pasyutin

38. AVP RF F.581 Op.20 P.24 D.1 L.94 Turmachev's Diary. Conversation with Head of the Ministry of Culture and High Education of Somali Republic, June 14, 1976

39. AVP RF F. 586 Op.20 P.24 D.3 Reference of the Soviet Embassy

40. AVP RF F.581 Op.19 P.23 D.4 L.11 Conversation between Deputy Minister Sofinskiy and Somali Ambassador A. Adan, July 15, 1975

41. AVP RF F. 586 Оп.21 П.25 Д.2 Л.60-61 G.Dorokhin's Diaries. Conversation with Said Mahado. November, 2, 1977

42. AVP RF F. 581 Op.22 P.26 D.2 L.3 Sinitsin's Diaries. Conversation with Somali counsellor I.A. Warsame, January 24, 1978

43. In 2016 there was a story of a Russian woman called Farxiya, she started a search of her Somali father who disappeared about 40 years ago. She published everything she knew about him on a Somali site. In her words, he studied in a Military Academy in Saint-Petersburg in 1977, then due to Soviet-Somali conflict was transferred to Odessa and then he got lost. The Somali community traced the man and soon the woman met her father.

44. The following information is for reference and requires further detail. 